DOI 10.22363/2312-8143-2018-19-4-513-523

UDC 556.5(1/9)

\title{
Influence of the EI Niño phenomena on the climate change of the Ecuadorian coast
}

\author{
Antonio Fermín Campos Cedeno ${ }^{1}$, Junior Orlando Mendoza Alava ${ }^{1}$, \\ Evgenii K. Sinichenko ${ }^{2}$, Ilia I. Gritsuk ${ }^{2,3,4}$ \\ ${ }^{1}$ Universidad Técnica de Manabí \\ Avenida Urbina y Che Guevara, Portoviejo, Ecuador, 130105 \\ ${ }^{2}$ Peoples' Friendship University of Russia (RUDN University) \\ 6 Mikluho-Maklaya St., Moscow, 117198, Russian Federation \\ ${ }^{3}$ Russian Academy of Sciences Water Problems Institute (IWP RAS) \\ 3 Gubkina St., Moscow, 119333, Russian Federation \\ ${ }^{4}$ Moscow Automobile and Road Construction State Technical University (MADI) \\ 64 Leningradsky Prospect, Moscow, 125319, Russian Federation
}

\begin{abstract}
The climate on the Ecuadorian coast depends mainly on the marine currents of Humboldt and El Niño, which appear in the dry and rainy seasons, respectively. The Humboldt current is distinguished by being cold, while that of El Niño is hot. The presence of the El Niño current causes an increase in the evaporation of ocean waters with the consequent appearance of the rainy season. There are anomalous seasons of the El Niño stream, when the water temperature rises above the norm, higher than $25.5^{\circ} \mathrm{C}$, which has been called El Niño phenomena. The appearance of this natural phenomena has proven to be decisive in the climate change of the coast of Ecuador. In order to have technical information, important for the planning, control and development of the water resources of the DHM, in this research a temporal analysis of the monthly rainfall during 55 years, 1963-2017 period, is carried out. The National Institute of Hydrology and Meteorology of Ecuador (Instituto National de Meteorología e Hidrología - INAMHI) at station M005, located in the Botanical Garden of the Technical University of Manabí in Portoviejo, obtained these records. An analysis of the monthly and annual patterns is made, establishing that the El Niño events occurred in 1983, 1997 and 1998, have established guidelines for the change in the production of rainwater in the levels of intensity and temporal distribution, increasing the months of drought, while precipitation levels increase, concentrating in fewer months, basically in February and March. This is a situation that increases the water deficit, especially when there is not enough infrastructure of hydraulic works for the storage and regulation of runoff.
\end{abstract}

Keywords: hydrology, rainfall, monthly distribution, annually distribution, climate change, El Niño phenomena

\section{Introduction}

Since 1963, in accordance with the rainfall data recorded by the National Institute of Hydrology and Meteorology of Ecuador (INAMHI) Portoviejo-UTM meteorological station, the Province of Manabí has been experiencing an irregular behavior of the climate, 
reflected in the rainy periods, a primordial basis for the development of the agricultural sector.

In Manabí, about 30 years ago, according to testimonies of old farmers, the rains began in the middle or end of December, extending the month of May or mid-June.

Currently, the rainy periods begin in the middle or end of January and last only two and in some periods up to three months.

The climatic indicators that directly affect the behavior of the climate of the coastal region of Ecuador and especially the climate in Manabí, are the cold current of the South, also known as Humboldt, and the warm current of El Niño. The Humboldt current marks the cold and dry period for Manabí, whose influence exerts from mid-June to late November or mid-December, is characterized by the lack of rain and the presence in certain regions of the so-called winter "light rain" (garúa), at this time, the surface temperature of the sea water varies between 23 and $25^{\circ} \mathrm{C}[4 ; 6 ; 10]$.

From the middle to the end of December, the so-called El Niño warm current from the northwest or west gradually begins to manifest itself, so named because it appears in December, at the time of the celebration of Christmas. This current displaces the cold Humboldt current to the south, and at this time the water from the sea surface is heated with temperatures ranging between 25.5 and $27^{\circ} \mathrm{C}$, causing enough evaporation, which when transported by the wind, from the sea towards the continent, allows the formation of the clouds that cause the rains [2].

There is the so-called El Niño phenomenon, which is a difficult event to predict, characterized by a sudden change in the temperature of the surface sea water in the equatorial part of the Pacific Ocean and which has a decisive effect on the climate. In this phenomenon the hot zones near the surface move towards the east, the temperature of the ocean water exceeds $25^{\circ} \mathrm{C}$, evaporation accelerates, causing the production of rain in 5-6 times more than normal. The events of this phenomenon in the period under analysis have been 2, in the years 1983 and 1997-1998 [8; 9].

According to historical data from 1790 to the present date $7 \mathrm{El}$ Niño phenomena have arisen, with intervals of occurrence of $38,48,15,34,57$ and 15 years [1; 7]. These natural events, like those related to telluric movements, are considered stochastic and predicting the year of their next occurrence is impossible, but the truth is that their presence has been shown to mark the general climate, as it is demonstrated with the present investigation.

\section{Materials and Methods}

The basis for this work is the monthly rainfall records provided by the Ecuadorian Institute of Hydrology and Meteorology, meteorological station M005 located in the Botanical Garden of the Technical University of Manabí, latitude $01^{\circ} 02^{\prime 2} 26^{\prime \prime} \mathrm{S}$, length $80^{\circ} 27^{\prime} 54^{\prime \prime} \mathrm{W}$, period 1963-2017. Figure 1 shows the geographic location of station M005 within the territory of the Manabí Hydrographic Demarcation (DHM).

The total monthly precipitation records used in the investigation amount to 660 .

A temporal analysis of rainfall is made in 2 scenarios: 1) monthly; and, 2) annual.

The analysis period consists of 55 years. For the monthly analysis scenario, in accordance with rainfall patterns, three ranges of analysis were obtained: 1963-1982, 1984-1996, 1999-2017, extraordinary events of the El Niño phenomena of the years are excluded in the analysis 1983, 1997 and 1998, since these are non-normal events whose periodicity 
is difficult to predict, but which mark trends of climate change. The records used here total 660 . For each of the periods, the monthly variation coefficients were estimated with the help of the statistical formula [1;3]:

$$
C_{v}=\frac{\sigma}{\bar{x}}
$$

where $\sigma-$ standard deviation; $\bar{x}-$ arithmetic average.

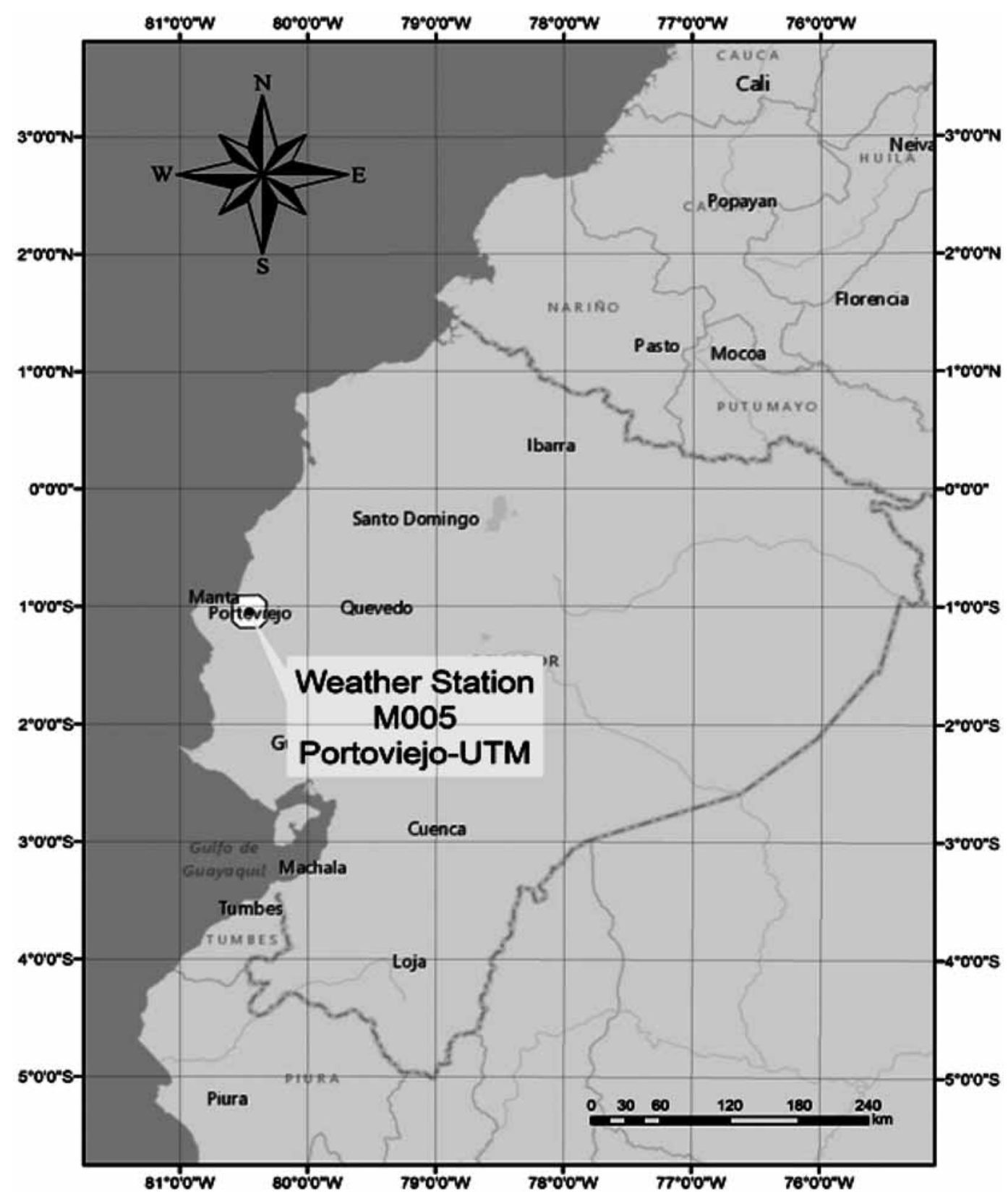

Figure 1. Location of the weather station M005 - Portoviejo-UTM 
For the scenario of the annual temporal analysis the total values are used, that is to say the sum of all the monthly precipitations, total 55 values of annual rainfall.

The annual precipitation was calculated as the sum of the monthly rainfall with the formula

$$
P_{a}=\sum_{i=1}^{12} P m_{i}
$$

where $P_{a}$ - annual rainfall; $P m-$ monthly rainfall.

Based on El Niño phenomena arising in the period 1963-2017, 3 analysis intervals have been considered: 1963-1982, 1984-1996 and 1999-2017, this is to determine the trends of variability of climate patterns in the region coast of Ecuador, before and after said phenomena.

For each of the periods considered, the average monthly rainfall values were determined with the formula

$$
P_{m m}=\frac{1}{n} \sum_{j=1}^{n} P m_{j}
$$

where $P_{m m}$ - average monthly rainfall; $n-$ number of years of the period; $P m_{j}-$ monthly rainfall.

For the periods 1963-1982, 1984-1996 and 1999-2017, 20, 13 and 19 years have been considered, respectively.

The calculations were carried out in Excel spreadsheets, to be then plotted in bars and statistical lines.

\section{Results and Discussion}

Of all the monthly rainfall records, the minimum value is $0.00 \mathrm{~mm}$, and the maximum value is $460.20 \mathrm{~mm}$. The average values of monthly rainfall for the period $1963-2017$ are contained in table, where it can be noted that the minimum value corresponds to the month of August, and the maximum value to February.

Table

Average values of monthly rainfall in mm, Portoviejo-UMT station (M005) Period 1963-2017

\begin{tabular}{|c|c|c|c|c|c|c|c|c|c|c|c|}
\hline JAN & FEB & MAR & APR & MAY & JUN & JUL & AUG & SEP & OCT & NOV & DEC \\
\hline 93.0 & 133.0 & 132.0 & 73.4 & 31.9 & 17.2 & 7.3 & 2.7 & 3.7 & 3.0 & 6.6 & 23.8 \\
\hline
\end{tabular}

In the monthly analysis of rainfall, in accordance with the 3 groups considered for the periods 1963-1982, 1984-1996 and 1999-2017, average monthly precipitation equal to $393.28,456.66$ and $546.80 \mathrm{~mm}$ was obtained, which indicates that there is a tendency to increase rainfall over time. However, by making a temporary monthly analysis of the distribution of rainfall for these periods, it has been detected that over time, the dry period has increased, becoming drier, which has a decisive impact on the agricultural sector due to the lack of enough water for the development of usual practices. 
Figures 2, 3 and 4 show this fact. Specifically, in figure 2, it is noted that there is greater uniformity in the distribution of precipitation, where August is the driest month with $1.16 \mathrm{~mm}$ and that the rainy period practically comprises 7 months: December, January, February, March, April, May and June, with a greater rainfall in the month of March, $107.69 \mathrm{~mm}$.

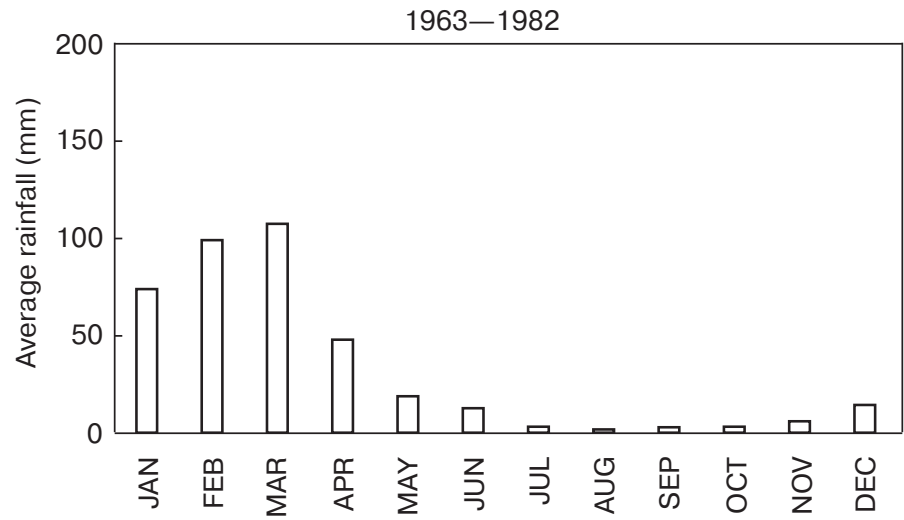

Figure 2. Average monthly rainfall, 1963-1982

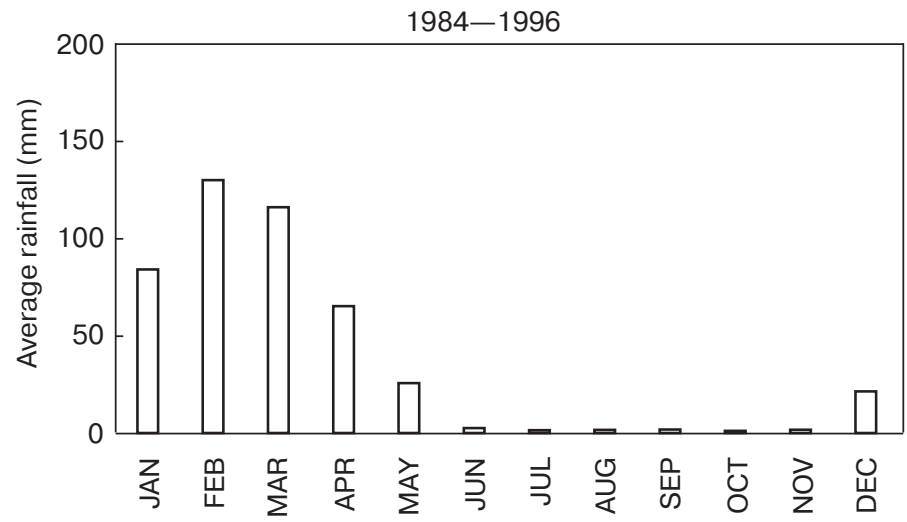

Figure 3. Average monthly rainfall, 1984-1996

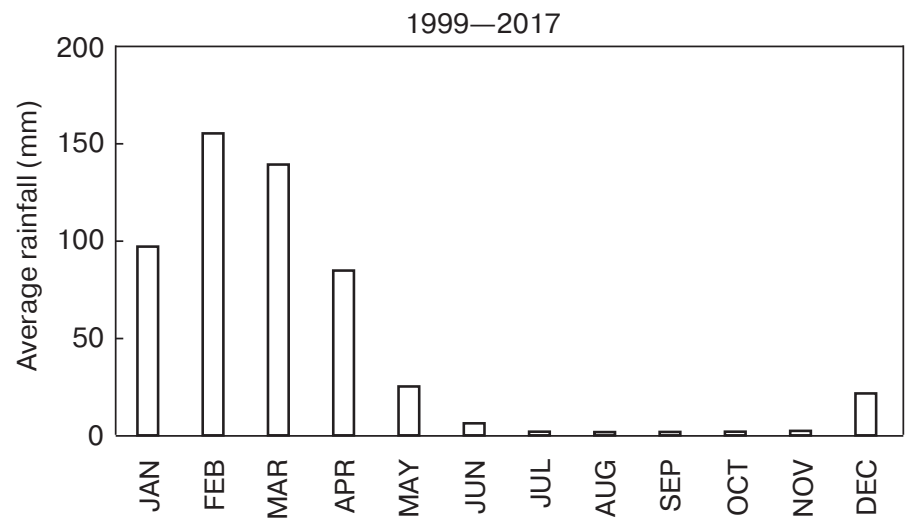

Figure 4. Average monthly rainfall, 1999-2017 
Figure 3 shows a distribution scheme a little different with respect to figure 2, here the rainy season includes 6 months, from December to June with maximum precipitation in the month of February, $131.65 \mathrm{~mm}$. The dry period is drier than in the previous case, where the precipitation is maintained almost equally for all months, with values that fluctuate between 1 to $2 \mathrm{~mm}$ per month, that is, almost nothing.

Figure 4, period 1999-2017, presents a scheme almost similar to that of figure 3, with a notable difference from the increase in rainfall in the month of February, $157.98 \mathrm{~mm}$. The dry period in this case, is drier than in the previous analysis with rainfall ranging between 0 and $1.5 \mathrm{~mm}$ per month, extreme drought.

The calculated coefficients of variation $C_{v}$ show that there is no uniformity of rainfall, since the values obtained fluctuate between $0.59-3.54$, which reinforces the fact of the disproportion of rainfall for rainy and dry periods.

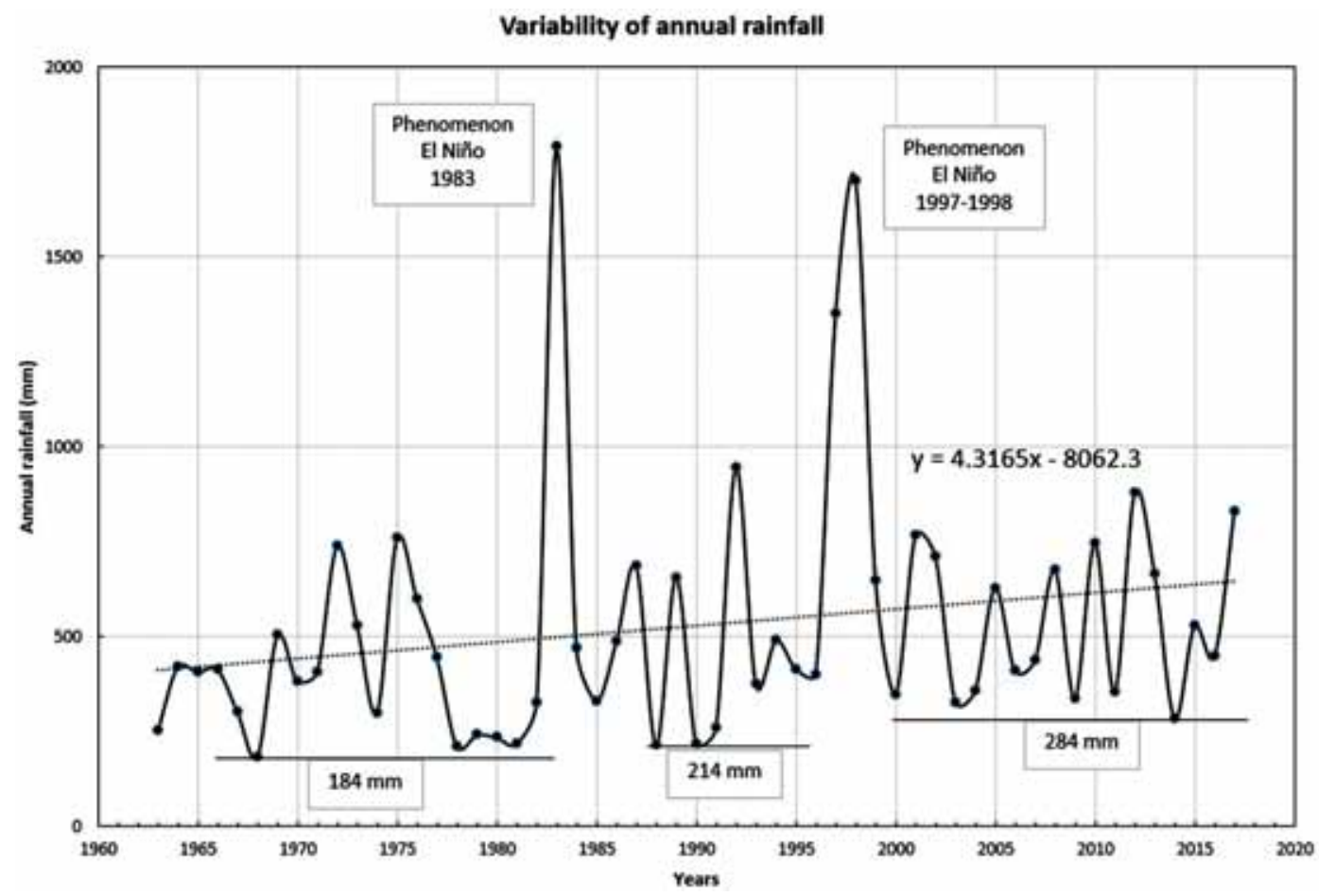

Figure 5. Variability of annual rainfall, 1963-2017

Figure 5 shows the variation of annual precipitation, noting, in general, a tendency to increase average rainfall over time. From a linear dispersion analysis [5] the following trend increase formula was obtained:

$$
y=4.3165 x-8062.3
$$

where $x$ - year of analysis; $y$ - average annual precipitation in $\mathrm{mm}$.

The appearance of El Niño phenomena, for the analysis period, shows changes in the production of rainfall patterns. Before the phenomenon happened in 1983, the minimum value of annual precipitations was of the order of $184 \mathrm{~mm}$, after the phenomenon, this 
value had an increase of $20 \mathrm{~mm}$, that is, it reached $214 \mathrm{~mm}$ (figure 5). After the phenomenon of 1997-1998, with respect to the previous minimum value, there was a rise of $70 \mathrm{~mm}$, reaching it to be located at $284 \mathrm{~mm}$ per year.

\section{Conclusions}

The climatic conditions, as far as the production of rainfall in the city of Portoviejo is concerned, and that directly affect the basin of the river of the same name (Pfafstetter 1514), from 1963 to 2017 have changed. This situation is directly associated with the appearance of the so-called El Niño phenomena of 1983 and 1997-1998. Figure 6 summarizes the distribution of average monthly precipitation for the periods of analysis, noting the gradual increase in precipitation in the rainy season, whose maximum values for the periods 1963-1982, 1984-1996 and 1999-2017, they are 107.7, 131.6 and $158.0 \mathrm{~mm}$, respectively. The opposite occurs with the minimum values of the average monthly precipitation in the dry period, which decrease, reaching for the periods indicated, values of $1.16,0.44$ and $0.43 \mathrm{~mm}$, respectively.

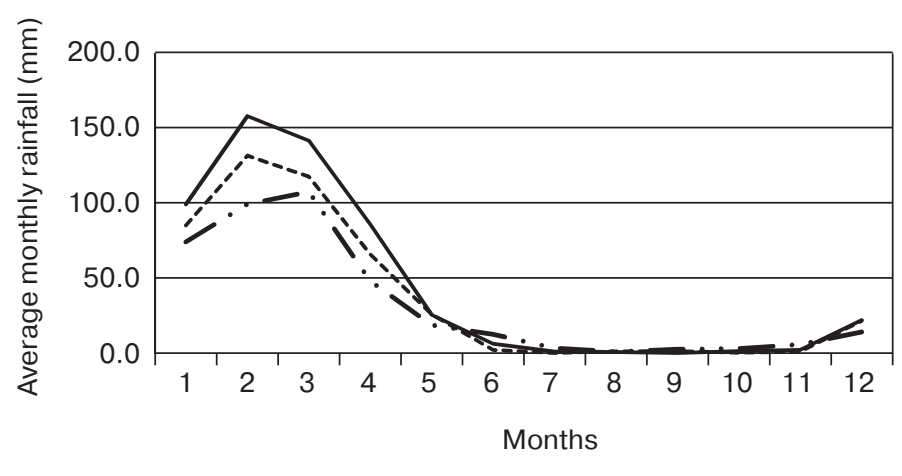

$-\cdots-1963-1982$
Figure 6. Average monthly rainfall

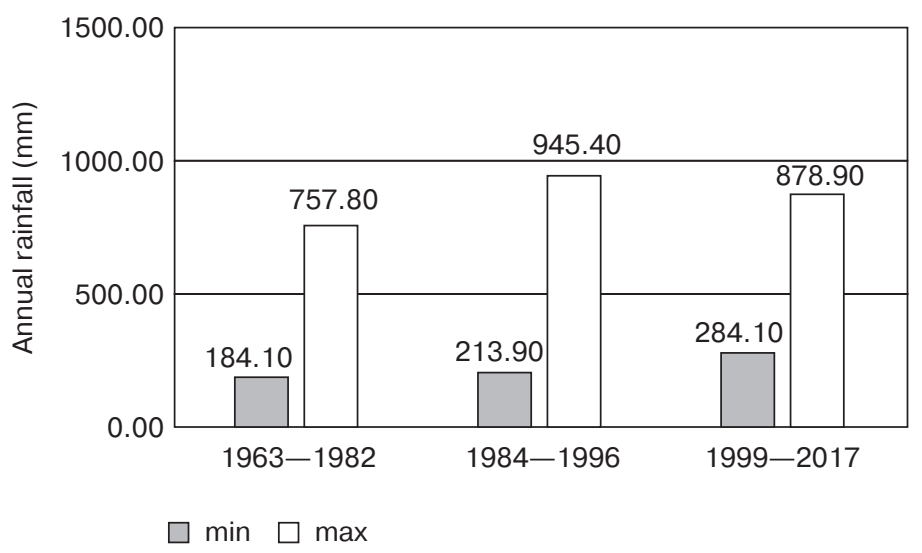

Figure 7. Annual extreme rainfall

The minimum values of annual rainfall (figure 7), after the events of the El Niño phenomena for the periods considered, have had an increasing character, with values 
equal to 184, 214 and $284 \mathrm{~mm}$. Regarding the maximum values, from the period 1963 1982 to $1984-1996$ there was an increase of $187 \mathrm{~mm}$, while between the periods 1984 1996 and 1999-2017, there was a slight decrease of $66 \mathrm{~mm}$.

It is evident that the general panorama tends to an increase in rainfall levels but with a shortening of the rainy season time with the consequent lengthening of the dry season, which would aggravate the existing deficit problem in the province. It is imperative to design and put into operation hydrotechnical works for the storage and regulation of surface runoff.

\section{References}

[1] Campos A. F., Sinichenko E. K. Características de Sistemas Fluviales Pequeños y Recursos Hídricos de la Demarcación Hidrográfica de Manabi, Perspectivas de Desarrollo. Moscú: Universidad de la Amistad de los Pueblos de Rusia, 2017, 42-45.

[2] Ismaiylov G. J., Perminov A. V. Balance Hidrico Mundial y Recursos Hídricos de la Tierra, Catastro del Agua y Supervisión de los Elementos Hídricos. Moscú: FGBOU MGUP, 2013, 324.

[3] Valinova V.S. Coeficiente de variación y coeficiente de determinación. 2016. Access mode: http:// univer-nn.ru/statistika/koefficient-variacii/

[4] Plan Integral de Desarrollo de los Recursos Hídricos de la Provincia de Manabí (PHIMA). Centro de Rehabilitación de Manabí. Manabi - Ecuador, 1989.

[5] Chereque Morán W. Hidrología para estudiantes de ingeniería civil. Lima, 1989, 236.

[6] Comisión Mixta de Cooperación Amazónica - Ecuatoriano - Colombiana. Plan de Ordenamiento y Manejo de las Cuencas de los Ríos San Miguel y Putumayo. Washington, D.C.: Secretaria ejecutiva para asuntos económicos y sociales, 1987.

[7] Cuenca N. Gestion de Recursos Hídricos en el Ecuador. 2008. Access mode: http://memorias. utpl.edu.ec/sites/default/files/documentacion/periodismo2013/utpl-Gestion-RecursosHidricos-Ecuador.pdf

[8] Instituto Nacional de Hidrología y Meteorología. Anuarios Meteorológicos. Instituto Nacional de Hidrología y Meteorología. 2015. Access mode: http://186.42.174.231/index.php/clima/ anuarios-meteorologicos

[9] Instituto Nacional de Meteorología e Hidrología del Ecuador. Hidrologia y meteorología. Instituto Nacional de Meteorología e Hidrología del Ecuador. 2015. Access mode: http://www. serviciometeorologico.gob.ec/

[10] Gobierto Autónomo Descentralizado del Cantón Portoviejo. Plan de desarrollo y ordenamiento territorial del cantón Portoviejo. GAD Portoviejo, 2011, 7-12.

(C) Campos Cedeno A.F., Mendoza Alava J.O., Sinichenko E.K., Gritsuk I.I., 2018

This work is licensed under a Creative Commons Attribution 4.0 International License

\section{Article history:}

Received: May 08, 2018

Revised: September 09, 2018

Accepted: September 28, 2018

\section{For citation:}

Campos Cedeno A.F., Mendoza Alava J.O., Sinichenko E.K., Gritsuk I.I. (2018). Influence of the El Niño phenomena on the climate change of the Ecuadorian coast. RUDN Journal of Engineering Researches, 19(4), 513-523. DOI 10.22363/2312-8143-2018-19-4-513-523 


\title{
Bio Notes:
}

Antonio Fermín Campos Cedeno - Ph.D., Associate Professor, Universidad Técnica de Manabí. Research interests: hydraulics, engineering hydrology, hydrotechnical construction. Contact information: e-mail: acampos@utm.edu.ec

Junior Orlando Mendoza Alava - Associate Professor, Universidad Técnica de Manabí. Research interests: hydraulics, engineering hydrology. Contact information: e-mail: jmendoza7865@utm. edu.ec

Evgenii K. Sinichenko - Ph.D., Associate Professor of the Construction Department, Engineering Academy, Peoples' Friendship University of Russia (RUDN University). Research interests: hydraulics, engineering hydrology. Contact information: e-mail: sinichenko_ek@pfur.ru

Ilia I. Gritsuk - Ph.D., Associate Professor of the Construction Department, Engineering Academy, Peoples' Friendship University of Russia (RUDN University). Senior researcher of laboratory "Channel flow dynamics and ice thermal conditions", Russian academy of Sciences Water Problems Institute. Associate Professor of the Hydraulic Department, Moscow Automobile and Road Construction State Technical University. Research interests: hydraulics, engineering hydrology. Contact information: e-mail: gritsuk_ii@pfur.ru

Научная статья

\section{Влияние явления Эль-Ниньо на изменение климата эквадорского побережья}

\author{
А.Ф. Кампос Седеньо ${ }^{1}$, Д.О. Мендоза Алава ${ }^{1}$, Е.К. Синиченко ${ }^{2}$, И.И. Грицук ${ }^{2,3,4}$ \\ ${ }^{1}$ Технический университет Манаби \\ Эквадор, 130105, Портовьехо, проспект Урбина и Че Гевары \\ ${ }^{2}$ Российский университет дружбы народов \\ Российская Федерация, 117198, Москва, ул. Миклухо-Маклая, 6 \\ ${ }^{3}$ Институт водных проблем РАН \\ Российская Федерация, 119333, Москва, ул. Губкина, 3 \\ ${ }^{4}$ Московский автомобильно-дорожный государственный технический университет \\ Российская Федерация, 125319, Москва, Ленинградский проспект, 64
}

Климат на побережье Эквадора зависит главным образом от морских течений Гумбольдта и Эль-Ниньо, которые появляются в сухие и дождливые сезоны соответственно. Течение Гумбольдта отличается холодными водными массами, а Эль-Ниньо - теплыми. Присутствие течения Эль-Ниньо вызывает увеличение испарения океанских вод с последующим появлением сезона дождей. Существуют аномальные сезоны течения Эль-Ниньо, когда температура воды поднимается выше нормы (выше $25,5^{\circ} \mathrm{C}$ ) - это называется явлением Эль-Ниньо. Появление этого природного явления оказалось решающим в изменении климата побережья Эквадора. Чтобы получить информацию, необходимую для планирования, контроля и развития водных ресурсов Эквадора, в работе проводится временной анализ данных натурных наблюдений за ежемесячными осадками в течение 55 лет (с 1963 по 2017 год). Используемые 
сведения были получены Национальным институтом гидрологии и метеорологии Эквадора (INAMHI) на станции М005, расположенной в Ботаническом саду Технического университета Манаби в Портовьехо. Исследование ежемесячных и ежегодных объемов осадков показало, что явления Эль-Ниньо, произошедшие в 1983, 1997 и 1998 годах, являлись решающими в увеличении объемов, уровнях интенсивности и временного распределения дождевых осадков. Однако в основном в феврале и марте концентрация осадков в течение месяца уменьшается, что приводит к увеличению дефицита воды, связанного с недостаточным количеством регулирующих емкостей (водохранилищ) по всей территории Эквадора.

Ключевые слова: гидрология, осадки, ежемесячное распределение, ежегодное распределение, изменение климата, явление Эль-Ниньо

\section{Список литературы}

[1] Кампос А.Ф., Синиченко Е.К. Характеристики малых речных систем и водные ресурсы гидрографической демаркации Манаби, перспективы развития: монография. М.: РУДН, 2017. $241 \mathrm{c}$.

[2] Исмайылов Г.Х., Перминов А.В. Мировой водный баланс и водные ресурсы земли, водный кадастр и мониторинг водных объектов: учебник для вузов. М.: Изд-во ФГБОУ МГУП, 2013. $324 \mathrm{c}$.

[3] Valinova V.S. Coeficiente de variación y coeficiente de determinación. 2016. URL: http://univernn.ru/statistika/koefficient-variacii/ (дата обращения: 20.04.2018).

[4] Plan Integral de Desarrollo de los Recursos Hídricos de la Provincia de Manabí (PHIMA) / Centro de Rehabilitación de Manabí. Manabi - Ecuador, 1989.

[5] Chereque Morán, W. Hidrología para estudiantes de ingeniería civil. Lima, 1989. 236 p.

[6] Comisión Mixta de Cooperación Amazónica - Ecuatoriano - Colombiana. Plan de Ordenamiento y Manejo de las Cuencas de los Ríos San Miguel y Putumayo. Washington, D.C.: Secretaria ejecutiva para asuntos económicos y sociales, 1987.

[7] Cuenca N. Gestion de Recursos Hídricos en el Ecuador. 2008. URL: http://memorias.utpl.edu. ec/sites/default/files/documentacion/periodismo2013/utpl-Gestion-Recursos-HidricosEcuador.pdf

[8] Instituto Nacional de Hidrología y Meteorología. Anuarios Meteorológicos / Instituto Nacional de Hidrología y Meteorología. 2015. URL: http://186.42.174.231/index.php/clima/anuariosmeteorologicos

[9] Instituto Nacional de Meteorología e Hidrología del Ecuador. Hidrologia y meteorología / Instituto Nacional de Meteorología e Hidrología del Ecuador. 2015. URL: http://www. serviciometeorologico.gob.ec/

[10] Gobierto Autónomo Descentralizado del Cantón Portoviejo. Plan de desarrollo y ordenamiento territorial del cantón Portoviejo. GAD Portoviejo, 2011. Pp. 7-12.

\section{История статьи:}

Дата поступления в редакцию: 08 Мая 2018

Дата поступления доработанного текста: 09 сентября 2018

Дата принятия к печати: 28 сентября 2018

\section{Для цитирования:}

Campos Cedeno A.F., Mendoza Alava J.O., Sinichenko E.K., Gritsuk I.I. Influence of the El Niño phenomena on the climate change of the Ecuadorian coast (Влияние явления Эль-Ниньо на изменение климата эквадорского побережья) // Вестник Российского университета дружбы народов. Серия: Инженерные исследования. 2018. Т. 19. № 4. С. 513-523. DOI 10.22363/2312-8143-2018-19-4-513-523 


\section{Сведения об авторах:}

Кампос Седеньо Антонио Фермин - кандидат технических наук, доцент Технического университета Манаби (Эквадор). Область научных интересов: гидравлика, инженерная гидрология, гидротехнические сооружения. Контактная информация: e-mail: acampos@utm. edu.ec

Мендоза Алава Джуниор Орландо - преподаватель Технического университета Манаби (Эквадор). Область научных интересов: гидравлика, инженерная гидрология. Контактная информация: e-mail: jmendoza7865@utm.edu.ec

Синиченко Евгений Константинович - кандидат технических наук, доцент департамента строительства Инженерной академии, Российский университет дружбы народов. Область научных интересов: гидравлика, инженерная гидрология. Контактная информация: e-mail: sinichenko_ek@pfur.ru

Грииук Илья Игоревич - кандидат технических наук, доцент департамента строительства Инженерной академии, Российский университет дружбы народов. Старший научный сотрудник лаборатории динамики русловых потоков и ледотермики, Институт водных проблем РАН. Доцент кафедры гидравлики, Московский автомобильно-дорожный государственный технический университет. Область научных интересов: гидравлика, инженерная гидрология. Контактная информация: e-mail: gritsuk_ii@pfur.ru 